\title{
Diverse Voices: \\ Middle Years Students' Insights into Life in Inclusive Classrooms
}

\author{
Jennifer Katz and Marion Porath \\ The University of British Columbia \\ Charles Bendu and Brent Epp \\ The University of Manitoba
}

\begin{abstract}
Thirty-one middle school students (grades 4-7) were interviewed at length about their perspectives regarding academic and social inclusion of students with disabilities; the barriers they perceive to a compassionate, inclusive learning community; and what they believe helps overcome these barriers. In discussing the inclusion of students with disabilities, participants were eloquent in their empathy for the challenges students with disabilities faced, while also articulating barriers to their willingness to include students with disabilities in their academic life based on pressures of the current school system, such as grades and pace, and the stigma associated with the presence of an educational assistant.
\end{abstract}

Internationally, today's classrooms are more diverse than ever before (Karangwa, Miles, \& Lewis, 2010; Mowat, 2010; Schirmer \& Casbon, 1995). In modern, inclusive classrooms, students learn alongside peers from diverse nations, cultures, races, family structures, and socioeconomic classes. Students often learn in multi-grade combinations, with students of diverse abilities, languages, background experiences, and learning styles. They are, therefore, exposed to multiple belief systems, values, relationship styles, cognitive understandings, and social rules. In the midst of this rich complexity, youth are attempting to master curricular understandings and skills, behave in socially acceptable and appropriate ways, and develop citizenship and social skills.

In many cases, classrooms inclusive of students with disabilities have been shown to benefit students both socially and academically (Cole, Waldron, \& Majd, 2004; Crisman, 2008; Katz $\&$ Mirenda, 2002a, 2002b). However, rising rates of bullying and mental health issues have raised concerns regarding students' ability to successfully negotiate complex developmental social and emotional challenges (Hymel, Schonert-Reichl, \& Miller, 2006; Modrcin-McCarthy \& Dalton, 1996). Alienation has been shown to increase for students with diverse learning profiles (Brown, Higgins, Pierce, Hong, \& Thoma, 2003). Combating bullying and alienation, therefore, 
requires instilling in children a respect for themselves, and for all people regardless of ability or appearance. As a result, social and academic inclusion have become increasingly important topics of research and practice in Canada and around the world (Calabrese, et al., 2008).

There are many definitions of inclusive education/inclusion. In our view, inclusive education is about every child's right to participate and the school's duty to accept and serve every child. A premium is placed upon full participation by all students and upon respect for their social, civil, and educational rights. Thus, social inclusion means that all students have a sense of belonging, of being included and cared for, and of interconnectedness with something larger than themselves - of being a part of a community. This requires that all students are a part of the social life of the classroom, and thus have extensive opportunities to interact with their peers, develop friendships, and have their families interact with other families. Academic inclusion, similarly, implies that all students are a part of the life of the classroom. This means that they learn in interaction with their peers - not separately or parallel, and not solely through adult (e.g., educational assistant) support.

Despite a growing body of research documenting positive effects of inclusion, a significant percentage of students with exceptionalities continue to be excluded from the regular classroom (Canadian Council on Learning, 2007). While inclusive education extends beyond just serving the needs of/including children with disabilities, it is clear that they remain one of the populations being excluded both socially and academically. For this reason, the researchers chose to focus this study, and this article, on the inclusion of students with disabilities, and the term will be used in this way throughout the rest of this article. It appears, in many cases, that educators have accepted the philosophy and need for inclusion; however, there remain complex issues relative to pre-service education, professional development, classroom management, collaboration, and inadequate supports and resources (Bennett, 2009). If inclusive education is to take hold, educators require the competence and confidence to teach students with exceptionalities in the classroom. Thus, it is paramount that inclusion be given priority in the education community.

Until recently, children have rarely been asked about their experiences in the education system (Dyson, 2005; Loreman, McGhie-Richmond, Barber, \& Lupart, 2009). However, as schools become increasingly diverse, and the complexity of the educational environment grows, it is less and less likely adults alone can know all there is to know about, and solve, all of the problems our students face. School professionals will rely on the invested participation of students in finding solutions. Student perspectives can improve educational programming by making curriculum more accessible, creating collaborative processes, empowering students, and motivating them to participate in their education (Cook-Sather, 2002). As Hodkinson (2010) eloquently put it, "A prerequisite for successful inclusion is the maintenance of a dialogue between those involved and those who experience this process" (p. 63).

Student attitudes to disability directly impact the social inclusion of students with disabilities. In general, students without disabilities in inclusive settings have been shown to possess predominantly positive attitudes toward their peers with disabilities. However, some barriers to academic and social inclusion do exist, such as grouping structures and social and academic isolation (Bunch \& Valeo, 2004). Thus, it is imperative to learn from students without disabilities what facilitates inclusive education and what may pose a barrier.

Students in the current study were enrolled in grade 4-7 classrooms in diverse, fully inclusive schools. These schools were a part of a public school division that had moved to full inclusion some 15 years earlier. Students in this school district came from 57 different countries, and most schools had at least $60 \%$ of their students studying English as a second or third lan- 
guage. The division was in a suburb of a major Canadian city and included neighbourhoods ranged in socioeconomic status from poverty level to upper middle-class. Thus students in this study had grown up experiencing cultural, linguistic, socioeconomic, and learning diversity in their communities and schools. They had lived and learned alongside students from other countries, who spoke many languages, and with students with mild, moderate, and significant disabilities and behavioural challenges. In the middle years, students are sufficiently articulate to be able to share insights and express opinions. For this reason, we chose to involve students of this age and community in a study exploring student perspectives regarding inclusive learning communities, the barriers to and facilitators of inclusion, and the outcomes of an intervention program to develop respectful learning communities.

This study is part of a larger study investigating the outcomes of a Social and Emotional Learning program (Katz \& Porath, 2011). In the first part of the study, reported in detail in Katz and Porath (2011), the Respecting Diversity (RD) program was introduced to 218 middle years students in the aforementioned school division as a vehicle for discussing respect for diversity, disability, and self-respect. The program is founded on work that demonstrates that students need to know how their mind works, recognize their strengths and challenges, know how to use their strengths to make choices for academic activities (e.g., choosing a project or elective course that suits their abilities), and see how their learning profile can make valuable contributions to their community and future career choices (Levine, 2001, 2002; Prescott, 2001) in order to develop self-respect and emotional resiliency. The program begins with lessons that are intended to facilitate these skills and proceeds to lessons intended to develop social awareness and respect (for more on the program, see Katz \& Porath, 2011).

Social awareness and respect allow students to appreciate diversity, develop respect and empathy for others, and gain an understanding of diverse learning profiles and the advantages to this diversity within a community (Peavey \& Leff, 2002; Smith, 1999). Valuing diversity increases students' tolerance for others' differences and allows students to manage their relationships within diverse learning communities in prosocial ways (Brandt, 1998; Jaouen, 1990). In the RD program, lessons are designed to facilitate these understandings and skills.

In the larger study, intervention and control groups were assessed pre and post intervention for level of self-awareness, self-respect, awareness of others, and respect for others. Measures of classroom climate were also included. Students completed several measures of social and emotional learning, and a selected sample, described subsequently, were interviewed to obtain detailed information about their experiences with the RD program. Data were analyzed using thematic content analysis procedures and repeated measures MANCOVAs. The intervention significantly increased students' self-respect, awareness of others, and respect for others, while students in control classrooms decreased in these factors. Classroom climate also significantly improved for treatment classrooms according to both teachers and students, and, similarly, decreased in control classrooms. Thematic analysis revealed that the opportunity to explore their own and others' learning profiles led to greater self-understanding and respect, as well as a more developed ability to perspective take and see value in diversity.

In the current study, 31 students who were involved in the larger study were presented with two case study scenarios intended to elicit student perspectives regarding social and academic inclusion. The case study scenarios were conducted pre and post intervention. The students' responses to them are the focus of this paper. 


\section{Purpose of the Study}

The following research question was addressed: What are the barriers to and facilitators of inclusion according to middle years students?

\section{Method}

\section{Participants}

Participants were drawn from a large suburban public school district in British Columbia, Canada. The district serves 22,512 students from grades $\mathrm{K}-12$. The district supports an inclusive model for all students. In this definition of full inclusion, all students attended their neighbourhood school and were enrolled in age appropriate regular education classrooms. Services were for the most part delivered in class through the use of educational assistants and co-teaching between resource teachers, ESL teachers, and classroom teachers. Some pull-out, short-term support (e.g., a 30-minute block three times a week) took place for such services as speech and language, physiotherapy, and occasionally, literacy intervention. Five schools volunteered to participate in the study. All schools enrolled students from K-Grade 7 and ranged in size from 300500 students. Percentage of students below the poverty line ranged from 20-33\% according to the Early Development Index (Hertzman, McLean, Kohen, Dunn, \& Evans, 2002). Student ESL populations in these schools ranged from $48-72 \%$.

Students for whom English was a second language made up $67.4 \%$ of the sample, which is common in the Lower Mainland of British Columbia. The dominant languages participants spoke were English and Asian in origin. Students were selected for interviews in which they were presented with case study scenarios based on grade and gender; a balanced sample was randomly selected (e.g., from all the Grade 4 girls, three students were randomly chosen). Of the 31 students, 10 students were in Grade 7 (five boys and five girls), 7 students were in Grade 6 (four boys and three girls), 7 students were in Grade 5 (three boys and four girls), and 7 students were in Grade 4 (four boys and three girls). Students who had severe cognitive disabilities or who had not developed sufficient proficiency in the English language to take part in the programs' activities and complete measurement scales and interviews were excluded from the study.

\section{Procedure}

Case study scenarios. The targeted sample of students described above was presented with two case study scenarios (see Appendix). In the first scenario, David, a student with Down syndrome, leaves a table at the back of a class where he had been working with his aide and approaches a group of peers requesting to work with them. In the second scenario, John, a student who is described as finding "reading and writing really hard" is assigned by the teacher to work with a group on a project. The group proposes that they all go and research some facts, to which John replies that he would prefer to go and find pictures on the internet while they collect the information. Questions focused on perspective taking ability (social awareness), attitudes to diverse others, empathy (respect for others), and barriers to and facilitators of inclusion. Students were asked (a) what they thought the student with disabilities was thinking/feeling in the scenario, (b) what the students without disabilities were thinking and feeling, and (c) whether the group should include or work with the student with disabilities and in what way/using what strategies. Half of the participants were given the John scenario initially and the David study post intervention. The other half received the scenarios in reverse order to control for time/intervention effects. Interviews and responses to the scenarios were audio-recorded and transcribed verbatim. 
For the purpose of this study, pre- and post-intervention transcripts were initially combined for a preliminary thematic analysis. That is, coders used open coding to derive themes from case study scenarios that were not identified as pre or post (transcripts had the words "pre" and "post" removed), in an effort to first identify general emergent themes. Following this, transcripts of the responses to the scenarios were separated in two ways: (a) pre and post intervention to determine whether the discussion about and exploration of learning styles/intelligences and the discussions of disability awareness and diversity in the RD program impacted students' attitudes and responses and (b) by scenario/disability to determine whether there was a difference in how students responded to John, a student with a mild/learning/hidden disability, and David, a student with a more severe/developmental/visible disability (Down syndrome). Four independent raters - two of whom were graduate students familiar with qualitative data analysis but not with the RD program or this study's research questions - coded the qualitative student data using thematic content analysis. Raters then shared their findings, and only emergent themes which had appeared in all of the raters' findings were carried forward. Following this, a discussion was held to further develop, combine, and clarify these themes.

\section{Results and Discussion}

Much has been said about the importance of social inclusion (Muijs et al., 2010). Students who feel a sense of belonging and have opportunities for positive peer interactions express more positive attitudes toward school; have fewer suspensions; and demonstrate improved attendance, retention, and academic engagement and achievement (Graham \& Harwood, 2011; Katz \& Mirenda, 2002a, 2002b). Clearly, the willingness of peers without disabilities to engage socially with students with disabilities is necessary for the social inclusion of students with disabilities to be successful. In addition, academic inclusion in modern inclusive classrooms frequently necessitates that students with disabilities work cooperatively with students without disabilities.

This research was designed to explore the attitudes and opinions of students without disabilities regarding both social and academic inclusion of students with disabilities. We wanted to discover, from students' own perspectives, what facilitated or hindered social and academic inclusion. Students spoke passionately and eloquently about the conflicting feelings they had between the empathic responses they felt for students with disabilities and the pressures of academic achievement and school "rules."

\section{The Evolution of the Themes}

Discussion amongst raters of the data began with a conversation about the empathy shown by students in the middle years toward the students in the case study scenarios, and David in particular. All the raters had immediately noted this theme. Given what we know about preadolescent tendencies toward egocentrism (Vartanian, 2000), and their emphasis on fitting in (Nichols, 2008; Warrington \& Younger, 2011), it was striking to note students' ability to take the perspective of a student who is socially and academically excluded, and empathize with them. Almost every student in the study responded to, "How do you think David is feeling?" with discussion of how sad he must be at "being left out" and "having no friends," and how he "just wants to be with everyone else." The importance of having friends and being a part of the life of the classroom was clear. As we discussed this theme, however, it began to come clear that the same empathy was not being shown to John, the student with an invisible disability. On separation of the transcripts and examination of them by case, a distinct difference became evident. John, who wanted to get the pictures off the Internet rather than collect facts with his group, was 
perceived as being lazy and uncooperative. There was little empathy for him pre intervention. When we further separated the transcripts to pre and post intervention, students showed considerably more empathy to John post intervention, suggesting the emergence of the themes of disability awareness and co-operative skills as being supportive of greater empathy and willingness to include. More detail about the nature of these themes will be discussed in the next section.

When we examined students' responses to the questions, "What are the group members thinking/feeling?" we were fascinated by the students' responses. They clearly felt conflictedthey empathized with David's desire for peers and friends, but had concerns about including him in terms of their marks and being able to complete the task on time. Some students were significantly impacted by the presence of the educational assistant-"Mr. Brown" appeared to stigmatize David as being different and "not normal."

The theme of the importance of peers further evolved as we looked at students' responses to the question, "What should they do?" While it is commonly understood that having friends and being socially included are of importance to students in the middle years (Nichols, 2008; Warrington \& Younger, 2011), we are not aware of literature that details students' views of the importance of friends "for learning." Yet here, it appeared that students believed that David and John needed friends not just for social and emotional reasons, but so they could learn. Students believed the adults were not holding high enough expectations of the students with exceptional needs, and that David and John would benefit from peers who would help them to learn. Ultimately, we organized these emergent themes into those that indicated positive supports for inclusion of students with disabilities and those that appeared to illuminate barriers to inclusion.

\section{Facilitators of Inclusion}

The themes identified as facilitative of inclusion are summarized in Table 1 and discussed below.

Empathy. When students were presented with the David scenario where it was clear the student had a disability and were asked what they would do, almost all expressed empathy and compassion for the student with a disability. Students expressed understanding that students with disabilities want friends, want to belong, and want to be liked for who they are:

He's sort of feeling left out because of his disability and he has to work with this guy, Mr. Brown. He really, really wants to work with the other kids that don't have disabilities. I guess he sort of feels like, even though I have a disability why should I be working with this guy. I'm like the same species as you guys, I'm not a dog, I'm not a monkey, why shouldn't I be able to work with you?

Disability awareness. When the disability was subtler, however, as in the John scenario, students focused on the task and the "unfairness" of him doing something different (looking up pictures) than the others in the group, “He's just slacking off, maybe he just doesn't want to do the reading; he'll just do all the easy stuff."

After discussing "challenges" and disabilities in the RD program, however, students gained a new perspective on the feelings and difficulties of students with learning disabilities, such as John, and responded with much greater empathy and insight:

He is feeling a little different and a little embarrassed. If he thinks that he'll work better doing, looking up pictures, he can do that. 
Table 1

Facilitators of Inclusion

\begin{tabular}{|c|c|c|}
\hline Theme & Description & Examples \\
\hline Empathy & $\begin{array}{l}\text { Students understand desire to belong, } \\
\text { have friends, be liked for who he is, em- } \\
\text { barrassment, fear of being disliked or } \\
\text { ridiculed. }\end{array}$ & $\begin{array}{l}\text { He's sort of feeling left out because of his } \\
\text { disability and he has to work with this } \\
\text { guy, Mr. Brown. He really, really wants to } \\
\text { work with, the other kids that don't have } \\
\text { disabilities. I guess he sort of feels like, } \\
\text { even though I have a disability why } \\
\text { should I be working with this guy. I'm like } \\
\text { the same species as you guys, I'm not a } \\
\text { dog, I'm not a monkey, why shouldn't I be } \\
\text { able to work with you? }\end{array}$ \\
\hline \multirow[t]{2}{*}{ *Disability awareness } & \multirow{2}{*}{$\begin{array}{l}\text { More empathy when disability visible or } \\
\text { explained. When student with learning } \\
\text { disability avoids/struggles without expla- } \\
\text { nation, students feel is unfair/lazy. }\end{array}$} & $\begin{array}{l}\text { Before demystification: He's just slacking } \\
\text { off, maybe he just doesn't want to do the } \\
\text { reading, he'll just do all the easy stuff. }\end{array}$ \\
\hline & & $\begin{array}{l}\text { After demystification: Um like, I think they } \\
\text { think John's different but he's just the } \\
\text { same as other people. Cause maybe they } \\
\text { think he is different, but he's not. He's just } \\
\text { the same as other people he just likes } \\
\text { doing different things in different ways. } \\
\text { They should try to cooperate more with } \\
\text { him so at least he feels more included } \\
\text { than like un-included. I think that they } \\
\text { should accept his talents and let him be. }\end{array}$ \\
\hline Learning from peers & $\begin{array}{l}\text { Students believe he will learn better from } \\
\text { them, needs friends to help him out-you } \\
\text { learn from your friends. }\end{array}$ & $\begin{array}{l}\text { Say yes, and help him to understand hard } \\
\text { books and teach him how to read hard } \\
\text { books. Because um he maybe not much } \\
\text { people help him out, maybe the teacher } \\
\text { only teaches him easy stuff and no friend } \\
\text { helps him out. }\end{array}$ \\
\hline *Skills & $\begin{array}{l}\text { Skills needed for task breakdown and } \\
\text { division of labour. }\end{array}$ & $\begin{array}{l}\text { Maybe they should let David do the art or } \\
\text { something, something that he can con- } \\
\text { tribute, something that he is good at. } \\
\text { Then the rest of the group can do the } \\
\text { reading, that he has trouble with, and } \\
\text { help him do it as well. } \\
\text { That's the way they want to do it but they } \\
\text { don't realize how frustrated John is and } \\
\text { how hard it is for him. They don't really } \\
\text { understand that it's frustrating for him and } \\
\text { they think that he can do it the same way } \\
\text { that they do, but he really can't...Try and } \\
\text { compromise so some people do the re- } \\
\text { search and reading, some people do the } \\
\text { writing and drawing and put it all together } \\
\text { in one big project. }\end{array}$ \\
\hline
\end{tabular}

Note. ${ }^{\star}$ Differences were noted in these themes before and after demystification.

Um like, I think they think John's different but he's just the same as other people. Cause maybe they think he is different, but he's not. He's just the same as other people he just likes doing different things in different ways. They should try to cooperate more with him so at least he feels more included than like un-included.

Thus disability awareness appears to play a key role in facilitating inclusion, in particular for students with hidden disabilities. However, it is not necessary for this awareness to identify individual students within the class as having a disability. The RD program uses a multiple intelligences framework to discuss the idea that we all have strengths and challenges, that everyone has something to contribute, and that a learning community is about making learning a "team 
sport" where we all support each other. It does not involve identifying individual students in the class.

It may also be that the differing approaches of David and John to the tasks influenced student attitudes. David sought to join, whereas John, at least in some students' eyes, appeared to be avoiding. With David, students respected that "he wants to try to learn with them. Um, just because I have special needs I want to try something new, something like challenging." In contrast, John appeared to be avoiding the task: "They think like John is a guy who doesn't like changing himself, just don't (sic) want to be better." This lost John respect and support. Admiration, effort, and initiative clearly influenced students' willingness to include. The willingness of David to apply effort and take initiative increased students' willingness to include him, in relative terms, as opposed to John.

Learning from peers. Students in the middle years place great value on having friends and a peer group (Nichols, 2008; Warrington \& Younger, 2011). Interestingly, students appeared to carry over this emphasis into learning. That is, they expressed a belief that "you need friends to help you learn." Thus, when asked what the group should do, most students responded that they should include or support the students with disabilities, so they could learn. They appeared to not see the value of the aide, Mr. Brown, who was working individually with David, as an important support for his learning; rather they focused on the importance of the peer group:

(They should) say yes, and help him to understand hard books and teach him how to read hard books. Because um he maybe not much people help him out, maybe the teacher only teaches him easy stuff and no friend helps him out.

I think the group should let him because he is a special needs kid he really should be with the other kids, to learn how they read and stuff like that. So that might really actually help him to learn how to read.

Skills. Finally, students expressed a need for support/guidance in learning the skills to work collaboratively and divide the learning task according to strengths and learning styles. When given an understanding of different intelligences and ways to approach learning through the RD program, they were able to specifically discuss how David could be included:

The group should do, um like since the level of intelligence like um the visual spatial people can do drawing. And then like um, yeah, like writing math and doing mathematics so maybe they should let David do the art or something, something that he can contribute, something that he is good at. Then the rest of the group can do the reading, that he has trouble with, and help him do it as well.

\section{Barriers to Inclusion}

Themes representative of barriers to inclusion are summarized in Table 2. Students expressed decidedly conflicting feelings when asked whether they would include David in their group. While, as noted above, they felt great empathy for him, there were three important barriers to their willingness to say yes to David joining them.

Grades: Students were often concerned that if they included David in their project, it would affect their final mark. While few, if any, teachers would actually take marks off a group mark because of the work of a student with a disability, perhaps teachers do not explicitly communicate this to students. As a result, students expressed concern about including David: 
Table 2

Barriers to Inclusion

\begin{tabular}{|c|c|c|}
\hline Theme & Description & Examples \\
\hline Grades & Working together will affect their mark. & $\begin{array}{l}\text { If they really care about their marks, so } \\
\text { they feel kind of bad because they don't } \\
\text { really want to, they feel bad that they are } \\
\text { going to exclude him but they don't really } \\
\text { want their marks messed up because he } \\
\text { is probably not going to really understand } \\
\text { the thing. He's probably like might not be } \\
\text { like good at writing it. }\end{array}$ \\
\hline Pacing & $\begin{array}{l}\text { Working together will slow them down, } \\
\text { prevent task completion. }\end{array}$ & $\begin{array}{l}\text { Maybe they don't want to include him in } \\
\text { because he might slow them down be- } \\
\text { cause they have to explain everything to } \\
\text { him. }\end{array}$ \\
\hline Educational Assistant & $\begin{array}{l}\text { Presence of Educational Assistant stig- } \\
\text { matizes the child. }\end{array}$ & $\begin{array}{l}\text { I think they should let David be in the } \\
\text { group because maybe they could learn } \\
\text { stuff from him and understand how he's } \\
\text { feeling. Maybe he will tell them what he } \\
\text { is feeling about being with an aide that } \\
\text { he's telling them l'm a normal person. } \\
\text { Normal people don't have aides. }\end{array}$ \\
\hline \multirow[t]{2}{*}{${ }^{*}$ Focus on cooperation } & $\begin{array}{l}\text { Collaboration is better than division of } \\
\text { labor, thus everyone needs to do all parts } \\
\text { to be "fair" and "equal." }\end{array}$ & $\begin{array}{l}\text { Before demystification: Uh, he needs to } \\
\text { read. Um, everyone is doing the same } \\
\text { thing and he is doing a different thing. }\end{array}$ \\
\hline & & $\begin{array}{l}\text { After demystification: The group should } \\
\text { do, um like since the level of intelligence } \\
\text { like um the visual spatial people can do } \\
\text { drawing. And then like um, yeah, like } \\
\text { writing math and doing mathematics. }\end{array}$ \\
\hline
\end{tabular}

If they really care about their marks, so they feel kind of bad because they don't really want to, they feel bad that they are going to exclude him but they don't really want their marks messed up because he is probably not going to really understand the thing. He's probably like might not be like good at writing it — they want to get an "A."

It appears, therefore, that if inclusion is to work, we must consider the nature of our assessment and evaluation processes. First, the emphasis on grades has always been controversial (Krogness, 1996). Second, the emphasis on assessment through written products puts many students at a disadvantage. Note that the student above assumes the students will have to "write it." While there is much discussion in the literature about differentiating instruction (LawrenceBrown, 2004), this has often not transferred to the differentiation of assessment (Brighton, Hertberg, Moon, Tomlinson, \& Callahan, 2005). If the group were allowed to present their understandings in another way, David might be better able to contribute to the group, and therefore be more welcome. Finally, when grades and tasks that emphasize verbal linguistic intelligence are assigned, teachers will need to find a way to explicitly communicate to students that their inclusion of students with language barriers or disabilities will not be to their detriment.

Pace. In a similar concern to that expressed around the issue of grades, students expressed concern that the inclusion of David would affect their ability to "get the task done" in the time allotted. Again, respondents assumed there would be time pressures on the project. This was not stated in the scenario, and most likely reflects students' experiences in their own education: 
"Maybe they don't want to include him in because he might slow them down because they have to explain everything to him."

While most teachers would agree that the optimal context for learning is having the time to learn with depth and breadth, teachers are often under time pressures, or believe they are, to "cover their curriculum." If we are to truly create inclusive learning communities where students who learn in a variety of ways and at varying paces are all valued and offered the opportunity to learn, we must find ways to remove this race through the curriculum and regain the true depth of education (Lawrence-Brown, 2004; Wiggins \& McTighe, 2005). This is not just in an effort to meet the needs of students with disabilities. Students who are gifted, for instance, often have a complexity of thought and process that requires more time to fully develop and produce a product (such as a project or essay), and clearly, based on the above quotes, typical students are feeling pressured to "just get it done," rather than the focus being on learning.

Aides. The use of educational assistants to support students with disabilities in inclusive classrooms is widespread. However, "the professional literature is nearly devoid of student outcome data as it pertains to the utilization of paraprofessionals" (Giangreco \& Doyle, 2002, p. 3). Social inclusion requires that students with disabilities interact with, develop friendships with, and at times, have conflicts and solve problems with students without disabilities, as all students do. However, there is some question about the preponderance of educational assistants' interference in these interactions. In one study exploring this issue, excessive proximity resulted in a series of problems such as (a) interference with teacher ownership and responsibility, (b) separation from classmates, (c) dependence on adults, (d) interference with peer interactions, (e) loss of personal control, (f) limitations on receiving competent instruction, and (g) interference with the instruction of the other students (Giangreco, Edelman, Luiselli, \& McFarland, 1997). Another study compared a peer-support strategy to paraprofessional support for students with profound disabilities in general education classes. The findings indicated that greater social interaction occurred with the peer-support strategy that benefited both students with and without disabilities. "Of the five peers without disabilities who provided supports, two showed no decrease in active classroom engagement, while three (who were identified as having academic problems) increased their active classroom engagement as a result of participating in the peer support strategy" (Giangreco, Edelman, Broer, \& Doyle, 2001).

Students appeared to be profoundly, and negatively, affected by the existence of an aide in the David scenario. For some students, David's leaving his educational assistant and coming over to them appeared to be "misbehaviour," and they worried they would get in trouble if they included him: "I think that they won't be very happy. Because that the teacher didn't chose (sic) David to be in their group and David is coming in their group." For others, the presence of an educational assistant marked David as so different that they did not believe he "belonged" with other kids: "People with special aides shouldn't be working with normal people." "Sandi's normal, and David has an aide." This suggests that the stigma was due to the presence of the educational assistant, and not his disability, as students did not say, "Well, he can't learn like us" or "He is different." They said, "People with aides are not normal." Students in this study attended schools in a full inclusion school division. The division had a disproportionate number of students with disabilities, as families who wanted their children included moved into the area. Most of the classrooms involved in this study included at least three students with significant disabilities (the contractual agreement with teachers), all had at least one, and all of the students would have had experience being in classrooms with students with disabilities and educational 
assistants. Thus it appears students were calling on their own experiences when they talked about students working with educational assistants.

Many of those who were willing to include David did so in part in reaction to the presence of the aide, assuming David wished he did not have one:

I think they should let David be in the group because maybe they could learn stuff from him and understand how he's feeling. Maybe he will tell them what he is feeling about being with an aide that he's telling them I'm a normal person.

Say yes and kind of work with him and then they might become friends after, then he will feel better in class, instead of working with Mr. Brown.

Interestingly, not a single student commented in a positive light about the presence of Mr. Brown (the aide). No student considered that in including David, the group would have the additional help of Mr. Brown - he was never seen as a positive addition. It appears, therefore, that the assignment of one-to-one aides to students with disabilities interferes with social and academic inclusion, rather than facilitating it.

\section{Conclusion}

Students in the middle years who have grown up in diverse, inclusive classrooms have extensive experience living and learning with students with disabilities, and can articulate the barriers and facilitators to inclusion. In this study, students confirmed some of the previous research literature's findings related to important aspects of inclusion such as the need for disability awareness (Krebs, 2000; Levison \& St. Onge, 1999), the importance of friendship and belonging (Purnell, 2007), the negative impacts of grades and time pressures (Krogness, 1996), and the social stigma that the presence of an aide can lead to (Giangreco, 2010). The majority of the students demonstrated notable empathy for the students with disabilities. However, in the John scenario, although they recognized that he was embarrassed and nervous, they focused on the need for him to challenge himself, get better at reading, and collaborate. In the David scenario, where the disability was more visible, the focus was on his feelings, rather than on the task. Much has been written about peer attitudes to students with disabilities (e.g., Bunch \& Valeo, 2004; McDougall, DeWit, King, Miller, \& Killip, 2004), but it is unclear what role the visibility of the disability plays. In addition, students expressed a need for strategies that enable them to successfully include a student with disabilities. After taking part in the RD program and learning about multiple intelligences, students felt more comfortable in determining a role for the student with disabilities to play, and were able to see the valuable contribution David and John could make, despite challenges with literacy.

On the other hand, there was an interesting absence of some issues we thought might surface. No student in the study worried that including David would socially stigmatize them. None of the students believed they could not work with David or that he was wrong to ask. It appears that growing up in diverse classrooms has enabled students to begin to close the social gap between themselves and children with disabilities.

This study has several implications for the field of inclusive education. First, it is important to provide students without disabilities with strategies and skills for working cooperatively with students with disabilities, and an awareness of both the gifts these students bring and the challenges these students face. Second, if we expect students without disabilities to be inclusive, we need to provide differentiated curriculum and assessment strategies for students of varying abilities and learning profiles, and be explicit with students about how marks will be awarded. 
Finally, the role of educational assistants in providing support for students with disabilities needs to be comprehensively evaluated and reformed, so that all students see the assistant as a support for their classroom, and not for individual students.

\section{Limitations of the Study}

The study was conducted using case study scenarios. The case study scenarios differed in several ways: level and type of disability, presence/absence of an aide, and task assigned. While this makes the cases more ecologically valid (a student with Down syndrome is more likely to have an assistant working one-on-one than is a student with a learning disability), it is difficult to draw conclusions about the reasons for students' responses. For instance, had the scenario with David been presented twice — once with an aide, and once without — it might have been clearer whether students' responses differed due to the visibility of the disability or the presence of the aide. Future research will need to focus on each variable individually in order to ascertain whether each of these factors individually impacts the perceptions of students without disabilities and responses to students with disabilities.

\section{References}

Bennett, S. (2009). Including students with exceptionalities. What Works? Research Into Practice, Research Monograph \#16, $1-4$.

Brandt, R. (1998). Powerful learning. Alexandria, VA: Association for Supervision and Curriculum Development.

Brighton, C. M., Hertberg, H. L., Moon, T. R., Tomlinson, C. A., \& Callahan, C. M. (2005). The feasibility of high end learning in a diverse middle school. University of Connecticut: National Research Center on the Gifted and Talented.

Brown, M. R., Higgins, K., Pierce, T., Hong, E., \& Thoma, C. (2003). Secondary students' perceptions of school life with regard to alienation: The effects of disability, gender, and race. Learning Disability Quarterly, 26, 227-239. doi:10.2307/1593636

Bunch, G., \& Valeo, A. (2004). Student attitudes toward peers with disabilities in inclusive and special education schools. Disability \& Society, 19(1), 61-77. doi:10.1080/0968759032000155640

Calabrese, R., Patterson, J., Liu, F., Goodvin, S., Hummel, C., \& Nance, E. (2008). An appreciative inquiry into the Circle of Friends program: The benefits of social inclusion of students with disabilities. International Journal of Whole Schooling, 4, 20-49. Retrieved from http://www.wholeschooling.net /Journal_of_Whole_Schooling/IJWSIndex.html

Canadian Council on Learning. (2007). Retrieved from http://www.ccl-cca.ca/ccl/Reports/SCAL/2007Archive /index.html

Cole, C. M., Waldron, N., \& Majd, M. (2004). Academic programs of students across inclusive and traditional settings. Mental Retardation, 42, 136-144. Retrieved from http://www.aaiddjournals.org/loi/mere.1

Cook-Sather, A. (2002). Authorizing students' perspectives: Toward trust, dialogue, and change in education. Educational Researcher, 31, 3-14. doi:10.3102/0013189X031004003

Crisman, B. W. (2008). Inclusive programming for students with autism. Principal, 88, 28-32. Retrieved from http://www.naesp.org/principal

Dyson, L. (2005). Kindergarten children's understanding of and attitudes toward people with disabilities. Topics in Early Childhood Special Education, 25, 95-105. doi:10.1177/02711214050250020601

Giangreco, M. F. (2010). Utilization of teacher assistants in inclusive schools: Is it the kind of help that helping is all about? European Journal of Special Needs Education, 25, 341-345. doi:10.1080/08856257.2010 .513537

Giangreco, M. F., \& Doyle, M. B. (2002). Students with disabilities and paraprofessional supports: Benefits, balance, and band-Aids. Focus on Exceptional Children, 34(7), 1-12. Retrieved from http://www .lovepublishing.com/catalog/focus_on_exceptional_children_31.html 
Giangreco, M. F., Edelman, S. W., Broer, S. M., \& Doyle, M. B. (2001). Paraprofessional support of students with disabilities: Literature from the past decade. Exceptional Children, 68, 45-63. Retrieved from http://www.cec.sped.org/Content/NavigationMenu/Publications2/ExceptionalChildren/default.htm

Giangreco, M. F., Edelman, S. W., Luiselli, T. E., \& McFarland, S. (1997). Helping or hovering? Effects of instructional assistant proximity on students with disabilities. Exceptional Children, 64(1), 7-18. Retrieved from http://www.cec.sped.org/Content/NavigationMenu/Publications2/ExceptionalChildren /default.htm

Graham, L. J., \& Harwood, V. (2011). Developing capabilities for social inclusion: Engaging diversity through inclusive school communities. International Journal of Inclusive Education, 15(1), 135-152. doi:10 $.1080 / 13603116.2010 .496208$

Hertzman, C., McLean, S., Kohen, D., Dunn, J., \& Evans, T. (2002). Early development in Vancouver: Report of the Community Asset Mapping Project. University of British Columbia, Human Early Learning Partnership, Vancouver.

Hodkinson, A. (2010). Inclusive and special education in the English educational system: Historical perspectives, recent developments and future challenges. British Journal of Special Education, 37, 61-67. doi:10.1111/j.1467-8578.2010.00462.x

Hymel, S., Schonert-Reichl, K. A., \& Miller, L. D. (2006). Reading, 'riting, and relationships: Considering the social side of education. Exceptionality Education Canada, 16, 149-192.

Jaouen, P. (1990). Fostering students' awareness of learning styles. Educational Leadership, 48, 14. Retrieved from http://www.ascd.org/publications/educational-leadership.aspx

Karangwa, E., Miles, S., \& Lewis, I. (2010). Community-level responses to disability and education in Rwanda. International Journal of Disability, Development and Education, 57, 267-278. doi:10.1080 /1034912X.2010.501183

Katz, J., \& Mirenda, P. (2002a). Including students with developmental disabilities in general education classrooms: Educational benefits. International Journal of Special Education, 17, 14-24. Retrieved from http://www.internationaljournalofspecialeducation.com/

Katz, J., \& Mirenda, P. (2002b). Including students with developmental disabilities in general education classrooms: Social benefits. International Journal of Special Education, 17, 25-35. Retrieved from http://www.internationaljournalofspecialeducation.com/

Katz, J., \& Porath, M. (2011). Teaching to diversity: Creating compassionate learning communities for diverse elementary school communities. International Journal of Special Education, 26(2), 1-13. Retrieved from http://www.internationaljournalofspecialeducation.com/

Krebs, C. S. (2000). Beyond blindfolds: Creating an inclusive classroom through collaboration. RE:view, 31, $180-186$.

Krogness, M. M. (1996). Giving grades: Laying an arcane ritual to rest. Voices from the Middle, 3, 23-26. Retrieved from http://www.ncte.org/journals/vm

Lawrence-Brown, D. (2004). Differentiated instruction: Inclusive strategies for standards based learning that benefit the whole class. American Secondary Education, 32(3), 34-62. Retrieved from http://www .ashland.edu/ase

Levine, M. (2001). Educational care. Cambridge, MA: Educators Publishing Service.

Levine, M. (2002). A mind at a time. New York, NY: Simon \& Schuster.

Levison, L., \& St. Onge, I. (1999). Disability awareness in the classroom: A resource tool for teachers and students. Springfield, IL: Charles C. Thomas.

Loreman, T., McGhie-Richmond, D., Barber, J., \& Lupart, J. (2009). Student perspectives on inclusive education: A survey of grade 3-6 children in rural Alberta, Canada. International Journal of Whole Schooling, 5, 1-12. Retrieved from http://www.wholeschooling.net/Journal_of_Whole_Schooling/IJWSIndex.html

McDougall, J., DeWit, D. J., King, J., Miller, L. T., \& Killip, S. (2004). High school-aged youths' attitudes toward their peers with disabilities: The role of school and student interpersonal factors. International Journal of Disability, Development and Education, 51, 287-313. doi:10.1080/1034912042000259242

Modrcin-McCarthy, M. A., \& Dalton, M. M. (1996). Responding to healthy people 2000: Depression in our youth, common yet misunderstood. Issues in Comprehensive Pediatric Nursing, 19, 275-290. doi:10 $.3109 / 01460869609026870$ 
Katz et al.

Mowat, J. G. (2010). Inclusion of pupils perceived as experiencing social and emotional behavioural difficulties (SEBD): Affordances and constraints. International Journal of Inclusive Education, 14, 631-648. doi:10.1080/13603110802626599

Muijs, D., Ainscow, M., Dyson, A., Raffo, C., Goldrick, S., Kerr, K.,...Miles, S. (2010). Leading under pressure: Leadership for social inclusion. School Leadership \& Management, 30, 143-157. doi:10.1080 $/ 13632431003663198$

Nichols, S. (2008). An exploration of students' belongingness beliefs in one middle school. The Journal of Experimental Education, 76(2), 145-169. doi:10.3200/JEXE.76.2.145-169

Peavey, K., \& Leff, D. (2002). Social acceptance of adolescent mainstreamed students with visual impairments. Journal of Visual Impairment \& Blindness, 96, 808-811. Retrieved from http://www.afb.org /jvib/jvib_main.asp

Prescott, H. M. (2001). Helping students say how they know what they know. Clearing House, 74, 237-243. doi:10.1080/00098650109599219

Purnell, P. G. (2007). Strategies for creating inclusive and accepting middle school classrooms. Middle School Journal, 39, 32-37. Retrieved from http://www.amle.org/Publications/MiddleSchoolJournal/tabid/435 /Default.aspx

Schirmer, B. R., \& Casbon, J. (1995). Inclusion of children with disabilities in elementary school classrooms. Reading Teacher, 49, 66-69. Retrieved from http://www.reading.org/general/publications/journals/rt .aspx

Smith, L. (1999). True diversity. Education Week, 18, 33. Retrieved from http://www.edweek.org/ew/index .html

Vartanian, L. R. (2000). Revisiting the imaginary audience and personal fable constructs of adolescent egocentrism: A conceptual review. Adolescence, 35, 639-661.

Warrington, M., \& Younger, M. (2011). "Life is a tightrope": Reflections on peer group inclusion and exclusion amongst adolescent girls and boys. Gender and Education, 23(2), 153-168. doi:10.1080 /09540251003674121

Wiggins, J., \& McTighe, J. (2005). Understanding by design. Alexandria, VA. Prentice Hall.

\section{Authors' Note}

Correspondence concerning this article should be addressed to Jennifer Katz, Department of Educational Administration, Foundations, and Psychology, The University of Manitoba, Winnipeg, MB, Canada, R3T 2N2. E-mail: Jennifer_Katz@umanitoba.ca

This study was supported by a grant to the first author from the Social Sciences and Humanities Research Council of Canada. 


\section{Appendix: Case Study Scenarios}

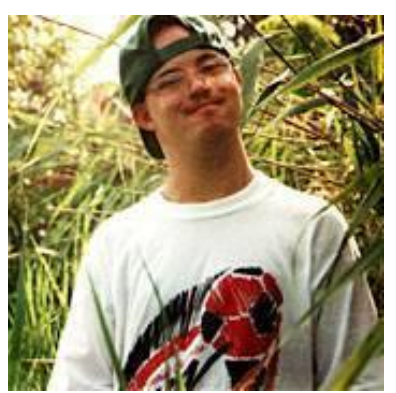

David was a grade 6 student with special needs. It took him longer to learn, and sometimes he acted like he was much younger than he was, even though he was really 11 years old. He had an aide who helped him learn in the classroom. David was really good at music and art, but he had trouble reading and understanding hard books.

The class was working on their novels. The students were sitting in groups, reading their book, and discussing what it meant. Then they were supposed to create a presentation for the class about their books.

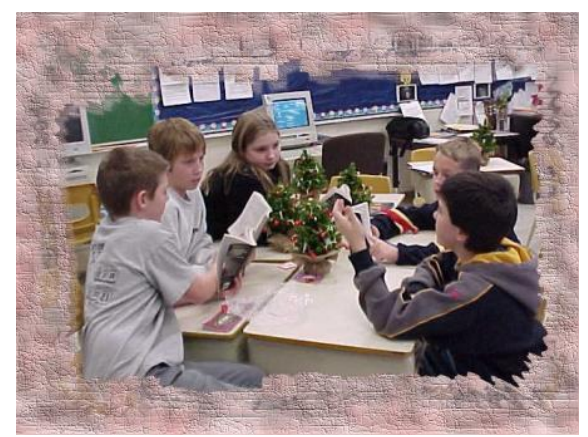

David was sitting at the back corner table with his aide, Mr. Brown. They were reading a book and talking about it. David got up and walked over to the table where Sandi's group was working. He looked at Sandi. "I want to work with you guys, ok?" he asked.

1. What do you think David is feeling? Why?

2. What do you think David is thinking? Why?

3. What do you think Sandi and the other group members are feeling? Why?

4. What do you think Sandi and the other group members are thinking? Why?

5. What do you think the group should do?

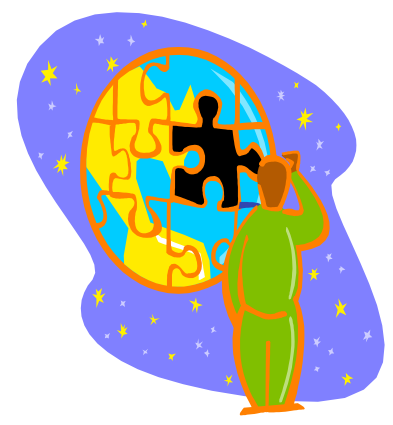

John, Sara, Jas, and Coco were working on their project. Their teacher, Ms. Miller, had asked the students to research a country of their choice, and then create a poster they would present to the class.

The group had decided to research Japan. They discussed what to do. Jas, Sara, and Coco thought they should all go and read books about Japan, and take notes about what they learned.

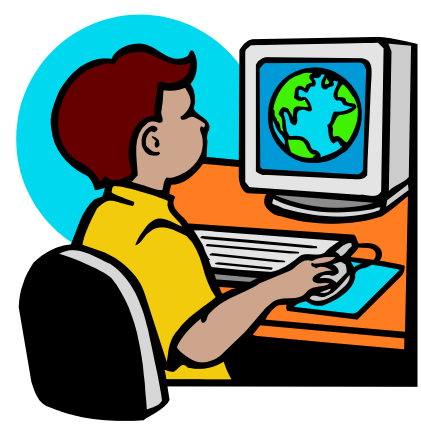

John didn't want to read books, reading was hard for him and he hated reading. So he said, "I don't want to read. I'll look at pictures on the net, and draw the poster. You all can read and do the writing for it."

1. What do you think John is feeling? Why?

2. What do you think John is thinking? Why?

3. What do you think the other group members are feeling? Why?

4. What do you think the other group members are thinking? Why?

5. What do you think the group should do? 